\title{
Fish community structure of Juramento reservoir, São Francisco River basin, Minas Gerais, Brazil
}

\author{
André R. M. Silva ${ }^{1,2}$; Gilmar B. Santos ${ }^{1} \&$ Thiago Ratton ${ }^{2}$ \\ 1 Programa de Pós-graduação em Zoologia de Vertebrados, Universidade Católica de Minas Gerais. Rua Dom José Gaspar \\ 500, prédio 41, 30535-610 Belo Horizonte, Minas Gerais, Brasil. E-mail: astyanax@pucminas.br \\ ${ }^{2}$ Centro Universitário UNA. Rua José Cláudio Resende 80, 30455-590 Belo Horizonte, Minas Gerais, Brasil.
}

\begin{abstract}
Many rivers in Brazil as the São Francisco (SFR) have been impounded for reservoirs construction purposes. However, there is a lack of knowledge on their fish fauna in many areas, including headwaters. The present study aimed to describe the fish community structure from Juramento reservoir, located on Juramento River, a branch of SFR basin. Six bimonthly samplings were made in four different sites. Gill and cast nets, beach seines and sieves were used to collect fish. Ecological indexes as well as the relationship between fish abundance and some limnological variables were determined. 3288 fish belonging to 33 species $(16.5 \%$ of the total described for SFR basin) were captured, being $75.7 \%$ Characiformes, $18.1 \%$ Siluriformes, 3\% Cyprinodontiformes and 3\% Gymnotiformes. Only two non-native species, 'tamboatá' - Hoplosternum littorale (Hancock, 1828) and 'trairão' - Hoplias lacerdae Ribeiro, 1908 were found. The highest catches in number occurred in the dry period (March-October) and the lowest one in the wet season (November-February). Diversity was higher at Barragem station and richness did not vary between reservoir zones. Five migratory species were found downstream of the dam (four exclusively there), whereas only the 'curimbatá-pioa' - Prochilodus costatus Valenciennes, 1850 occurred in the reservoir. The low observed correlations between fish abundance and the limnological variables utilized suggest that the local fish fauna is not strongly affected by their variation.
\end{abstract}

KEY WORDS. Fish diversity.

RESUMO. Estrutura da comunidade de peixes do reservatório de Juramento, bacia do Rio São Francisco, Minas Gerais, Brasil. No Brasil, vários rios, como os da bacia do São Francisco (RSF), são barrados para a formação de reservatórios. Entretanto, o estudo desta ictiofauna, especialmente a dos rios de cabeceira, ainda deixa a desejar. O presente estudo descreveu a estrutura da ictiofauna do reservatório de Juramento, Rio Juramento, bacia do RSF. Foram realizadas seis coletas bimestrais em quatro locais empregando-se redes de emalhar, tarrafas, arrastões e peneiras. Foram determinados índices ecológicos e a relação entre abundância da ictiofauna e algumas variáveis limnológicas do reservatório. Foram capturados 3288 exemplares, pertencentes a 33 espécies (16,5\% das descritas para a bacia do RSF), sendo 75,7\% Characiformes, $18,1 \%$ Siluriformes, $3 \%$ Cyprinodontiformes e 3\% Gymnotiformes. Apenas 2 espécies exóticas, tamboatá - Hoplosternum littorale (Hancock, 1828) - e trairão - Hoplias lacerdae Ribeiro, 1908 - foram capturadas. As maiores capturas em número ocorreram no período seco (março-outubro) e a menor durante a estação chuvosa (novembro-fevereiro). A diversidade foi maior em Barragem e a riqueza específica não variou entre as regiões do reservatório. Cinco espécies migradoras ocorreram a jusante (quatro exclusivamente ali), e apenas uma - Prochilodus costatus Valenciennes, 1850 - a montante. As baixas correlações entre a abundância de peixes e as variáveis limnológicas utilizadas, sugerem estar a ictiofauna local menos sujeita às alterações relacionadas a estas variáveis.

PALAVRAS-CHAVE. Diversidade de peixes.

Among the Brazilian rivers, the São Francisco (SFR) is distinguished for its extension, volume, economic and environmental importance. Its basin covers an area of $631,133 \mathrm{~km}^{2}$ (Planvasf 1989) representing 7.5\% of Brazilian territory. During its course of nearly 3,000 km from Espinhaço range toward the Atlantic Ocean, the SFR crosses through five States (Minas
Gerais, Bahia, Pernambuco, Sergipe and Alagoas) and three important biomas ('Cerrado', 'Caatinga' and Atlantic Forest) (COPASA 2001). Its central segment, from Pirapora city (Minas Gerais State) to Sobradinho reservoir (Bahia), comprises an area of 1,090 km plenty of marginal lagoons and floodplains, and produces overflows that can spread out to $84 \mathrm{~km}$ (average of 9 
$\mathrm{km}$ ) from its margins, as occurs at Xique-Xique (Bahia). The SFR floodplains areas are very important for fish recruitment, especially for migratory species nursery habitat (Pompeu \& GodinHo 2003, SATO \& GodinHo 2003). These species are among the more important ones to commercial fisheries, and allow the SFR to support an expressive fishery activity. Besides, mineral substances as lead, zinc, gold, silver, cadmium, chromium, quartz and sulfur have been extracted from that basin (COPASA 2001).

Studies involving SFR basin fish fauna are gradually increasing, calling attention, among other, some papers on inventory (BRiTSKi et al. 1986, SATO \& Godinho 1999), community structure (Alves \& Vono 1997, Alves \& POMPeu 2001), food habits (Pompeu 1999, Pompeu \& Godinho 2003, Oliveira et al. 2004) and fisheries (Godinho et al. 2003, SATo \& Godinho 2003).

However, information concerning the fish fauna of the SFR upper drainages, especially related to impounded areas, is poorly available yet. This is the current status of the Juramento reservoir, located in the headwaters of the Verde Grande river, where just one preliminary inventory (DABés et al. 2001) had been made. As the main water supplier for Montes Claros city (Minas Gerais), Southeastern Brazil, the study of its fish fauna is important to support the future management plan and the species conservation of that area.

The aims of the present study were to describe the structure of reservoir fish community. The species composition, spatial and temporal variations on the species abundance (in number and biomass), the assemblage constancy, richness, diversity and similarity between the sampled sites were determined. This study also intended to relate the reservoir fish abundance with some limnological variables.

\section{MATERIAL AND METHODS}

\section{Study area}

The Juramento reservoir $\left(16^{\circ} 46^{\prime} 20^{\prime \prime} \mathrm{S}\right.$ e $\left.43^{\circ} 39^{\prime} 56^{\prime \prime} \mathrm{W}\right)$ is owned by COPASA (Companhia de Saneamento de Minas Gerais). It was formed in 1981 by the Juramento river impoundment and has two tributaries (Saracura and Canoas rivers). Located $5 \mathrm{~km}$ far from Verde Grande river, it has a flooded area of $7.63 \mathrm{~km}^{2}, 9.1 \mathrm{~m}$ of mean depth and a total volume of 45 billions of liters. The reservoir was built in 1981 for supplying Montes Claros city, $27 \mathrm{~km}$ away. Currently, it is responsible for $70 \%$ of the total water supplied to that city. Juramento has a perimeter of $52 \mathrm{~km}$ at $640.3 \mathrm{~m}$, surrounded by $31 \mathrm{~km}^{2}$ of protected woody area. Its basin vegetation is characterized mainly by 'Cerrado' formations and pastures (DABÉs et al. 2001).

\section{Sampling}

Four sampling locals were defined in the study area: (1) Barragem, which represents the reservoir lentic zone; (2) Canoas, the transition region; (3) Juramento, the lotic area, and (4) Jusante, downstream the reservoir in front of the dam (Fig. 1).

Six bimonthly samplings were made for each upstream station from March 2002 to February 2003. Fish were caught using gill nets with mesh sizes from 3 to $16 \mathrm{~cm}$ (opposite knots length) soaked for 15 hours per station (from 16:00 PM to 7:00 AM). After this period, the nets were removed of water and all the fish captured were gathered by mesh size. Beach seines $(2 \mathrm{~mm}$ diameter), sieves $(2 \mathrm{~mm})$ and cast nets $(7 \mathrm{~cm})$ were also utilized.

In Jusante station it was not possible to apply the same sampling effort utilized upstream due to local limitations. Thus, just qualitative sampling was made there, using cast nets $(7 \mathrm{~cm}$ between opposite knots), gill nets $(7-8 \mathrm{~cm})$, beach seines and sieves ( $2 \mathrm{~mm}$ diameter).

In the field, specimens were identified, labeled and stored in $10 \%$ formaldehyde solution. In laboratory, from each specimen was obtained the standard length $(\mathrm{cm})$ and body weight (g). A small representative fraction of sampled fish has been deposited at Pontifícia Universidade Católica de Minas Gerais (PUCMinas). Few specimens were sent to Museu de Zoologia, Pontifícia Universidade Católica do Rio Grande do Sul, (PUCRS) for taxonomic confirmations.

Data on water temperature, conductivity, $\mathrm{pH}$, transparency, and dissolved oxygen from the stations upstream the dam were also collected by COPASA staff, from 9:15 to 10:55 AM at 0.5 m deep, from February 2002 to February 2003.

\section{Catches in number and biomass}

For the species captured by gill nets, fish abundance was determined through the capture per unit of effort (CPUE), defined as the sum of the number (CPUEn) or biomass (CPUEb) of captured fish by $100 \mathrm{~m}^{2}$ of nets soaked for 12 hours. This procedure allowed quantitative comparisons between species, stations and dry (March to October) and wet seasons (November to February). Before the analyses, two normality tests (Kolmogorov-Smirnov and Lillifors \& Shapiro-Wilks) were performed on abundance data. A one-way ANOVA was carried out to verify eventual significant abundance differences between the sampled stations, and a Tukey test was also applied when appropriated. A student t-test for independent samples was performed to verify significant differences in the abundance between dry and wet seasons. A 0.05 significance level was established for all tests utilized.

\section{Ecological parameters}

The cumulative curve of the species captured with gill nets was drawing along the sampling period to verify the influence of the number of samples on the species richness, following Boschung \& O'NEIL (1981), among other. The species constancy was calculated according to DAJOz (1973), for all the sampled stations including all species captured. The following categories were established: constant (equal or more than 50\%), accessory (equal or more than $25 \%$ and less than 50\%) and accidental (less than 25\%). The total number of species captured with gill nets was used as a richness index for each sampled station. Diversity was calculated using two different indexes that are not highly affected by sample size and that consider the relative abundance of each species to determine the diversity value 


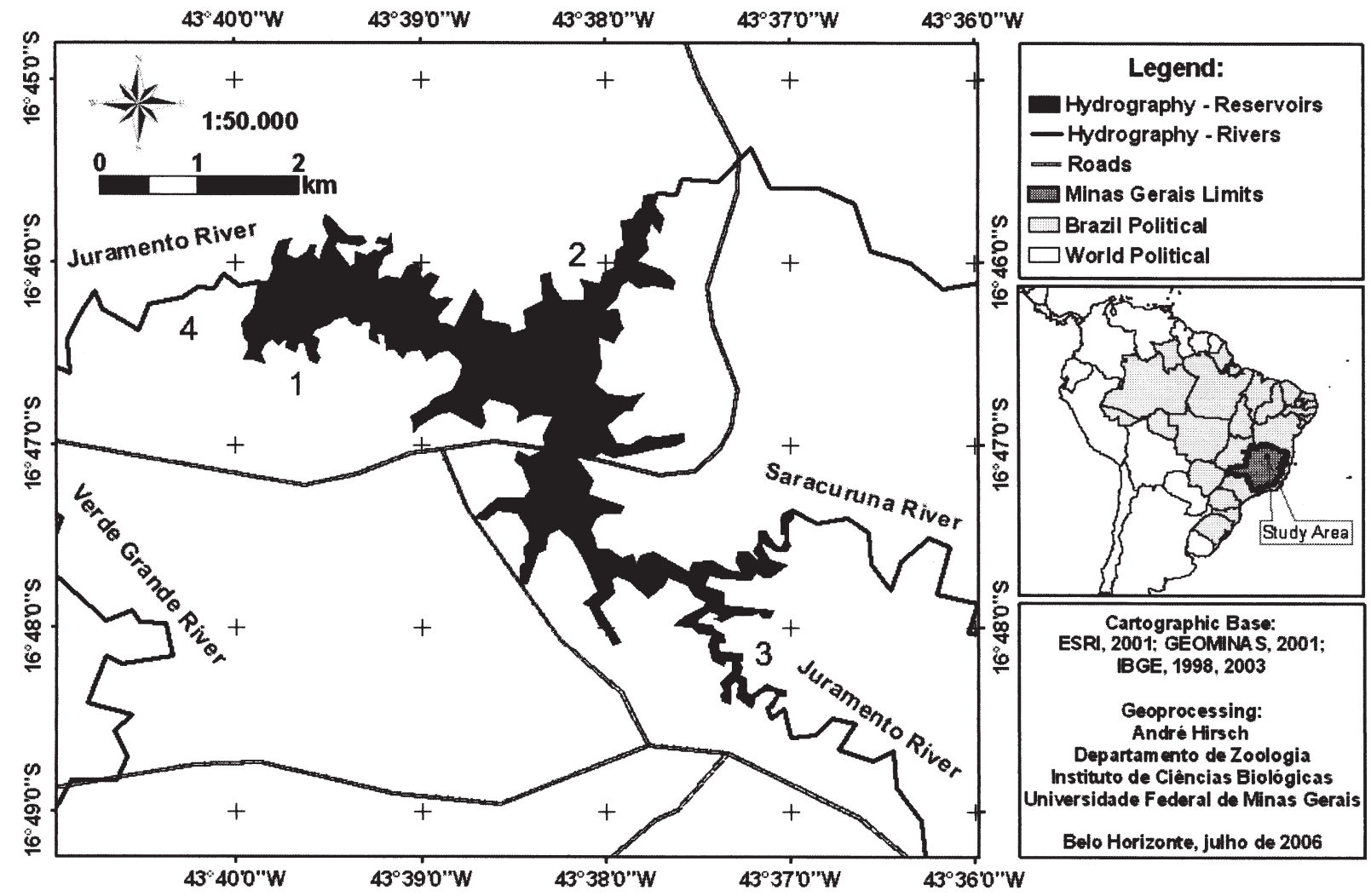

Figure 1. Juramento reservoir with the sampled areas: (1) Barragem, (2) Canoas, (3) Juramento, and (4) Jusante.

(MagurRan 2004). The Shannon index $\left(H^{\prime}\right)$ is represented by the equation $\mathrm{H}^{\prime}=-\Sigma[(\mathrm{ni} / \mathrm{N}) \cdot \operatorname{Ln}(\mathrm{ni} / \mathrm{N})]$, where: (ni) number of fishes of the ieth species found in a given local, $(\mathrm{N})$ total number of fishes captured in a given local, and $(\ln )$ natural logarithm. The Simpson index (1/D), is considered a measure of dominance, being sensible to the most abundant species. It is represented by the equation $\mathrm{D}=\Sigma(\mathrm{ni}(\mathrm{ni}-1)) / \mathrm{N}(\mathrm{N}-1)$, where: (ni) number of individuals of a given species and $(\mathrm{N})$ total number of individuals. The evenness index (E) is derived from the Shannon index and was calculated using the equation $E=H^{\prime} / \log S$, where $S=$ total number of species.

The resemblance between all the sampled stations was estimated through the Jaccard similarity index, following MAGURRAN (2004), taking in account only the species presence/ absence.

\section{Fish abundance and limnological variables}

To detect eventual relationships between the limnological variables utilized and fish abundance, a Principal Component Analysis (PCA) was performed over a matrix of previously log-transformed limnological data, according to TER BRAAK (1995). To avoid bias, only the components with eigenvalues greater than 1 were used for analyses, as pointed out by JACKSON (1993). To detect eventual patterns in the association degree, Pearson correlations were carried out between the principal axis and the log-transformed CPUEn values for each sampling and station.

\section{RESULTS}

A total of 3288 specimens were captured, belonging to 33 species and four different Orders. Twenty-five species $(75.7 \%)$ were Characiformes, whereas six (18.2\%) belonged to Siluriformes. Gymnotiformes and Cyprinodontiformes were represented by only one species each. Five species were found only upstream of the dam and 10 only downstream. From six Siluriformes species, five were only captured downstream, representing $50 \%$ of the species found exclusively at Jusante station (Tab. I).

The species cumulative curve showed a tendency to stabilization after the fifth sampling (November-December) (Fig. 2).

The CPUEn and CPUEb values between stations and seasons were not significant for the normality tests. No significant differences were also found for abundance (in number or biomass) between dry and wet seasons. Significant differences $(p<0.05)$ in CPUEn were only found between Canoas station and the other (Tab. II).

The 'pirambeba' Serrasalmus brandtii (Lutken, 1875) was the most captured species, corresponding to $22.4 \%$ of the all catches, followed by Curimatella lepidura (Eigenmann \& 
Table I. Fish species occurrence in the sampling sites of Juramento reservoir area, from March 2002 to February 2003. (Jus) Jusante, (Bar) Barragem, (Can) Canoas, (Jur) Juramento, (1) Qualitative captured species only, (2) Downstream captured species only, (3) Upstream captured species only, (4) Migratory species, (5) São Francisco river basin introduced species.

\begin{tabular}{|c|c|c|c|c|c|}
\hline \multirow{2}{*}{ Species } & \multirow{2}{*}{ Local name } & \multicolumn{4}{|c|}{ Sites } \\
\hline & & Jus & Bar & Can & Jur \\
\hline \multicolumn{6}{|l|}{ Characiformes } \\
\hline Acestrorhynchus lacustris (Lütken,1875) & Peixe-cachorro & + & + & + & + \\
\hline Apareiodon piracicabae (Eigenmann, 1907) & Canivete (1) & + & + & + & - \\
\hline Astyanax bimaculatus (Linnaeus, 1785) & Lambari-rabo-amarelo & + & + & + & + \\
\hline Astyanax fasciatus (Cuvier, 1819) & Lambari-rabo-vermelho (1) & + & + & - & + \\
\hline Brycon orthotaenia Günther, 1864 & Matrinchã $(2,4)$ & + & - & - & - \\
\hline Bryconamericus stramineus Eigenmann, 1908 & Piaba (1) & + & + & - & - \\
\hline Compsura heterura Eigenmann, 1915 & Piabinha (1) & + & + & + & - \\
\hline Curimatella lepidura (Eigenmann \& Eigenmann, 1889) & Manjuba (3) & - & + & + & + \\
\hline Hoplias lacerdae Ribeiro, 1908 & Trairão (5) & + & + & + & - \\
\hline Hoplias malabaricus (Bloch, 1794) & Traíra & + & + & + & + \\
\hline Leporinus elongatus Valenciennes, 1850 & Piau-verdadeiro $(2,4)$ & + & - & - & - \\
\hline Leporinus piau Fowler, 1941 & Piau-gordura (2) & + & - & - & - \\
\hline Leporinus taeniatus Lütken, 1875 & Piau-jejo (3) & - & + & + & + \\
\hline Moenkhausia costae (Steindachner, 1907) & Piaba (1) & + & + & + & + \\
\hline Phenacogaster fransciscoensis Eigenmann, 1911 & Piaba $(1,3)$ & - & + & - & - \\
\hline Piabina argentea Reinhardt, 1867 & Piaba (1) & + & + & + & - \\
\hline Prochilodus costatus Valenciennes, 1850 & Curimatá-pioa (4) & + & + & + & + \\
\hline Prochilodus argenteus Agassiz, 1829 & Curimatá-pacu $(2,4)$ & + & - & - & - \\
\hline Pygocentrus piraya (Cuvier, 1819) & Piranha & + & + & + & + \\
\hline Roeboides xenodon Reinhardt, 1851 & Piaba (1) & + & + & - & + \\
\hline Salminus brasiliensis (Cuvier, 1816) & Dourado $(2,4)$ & + & - & - & - \\
\hline Schizodon knerii (Steindachner, 1875) & Piau-branco & + & + & + & + \\
\hline Serrasalmus brandtii (Lütken, 1875) & Pirambeba & + & + & + & + \\
\hline Steindachnerina elegans (Steindachner, 1874) & Sagüiru (3) & - & + & + & + \\
\hline Tetragonopterus chalceus Spix \& Agassiz, 1829 & Piaba-rapadura & + & + & + & + \\
\hline \multicolumn{6}{|l|}{ Cyprinodontiformes } \\
\hline Poecilia vivipara Bloch \& Schneider, 1801 & Barrigudinho (1) & + & + & - & + \\
\hline \multicolumn{6}{|l|}{ Gymnotiformes } \\
\hline Eigenmannia virescens (Valenciennes, 1842) & Sarapó (1) & + & + & - & + \\
\hline \multicolumn{6}{|l|}{ Siluriformes } \\
\hline Otocinclus xakriaba Schaefer, 1997 & Cascudo (2) & + & - & - & - \\
\hline Hoplosternum littorale (Hancock, 1828) & Tamboatá $(1,2,5)$ & + & - & - & - \\
\hline Hypostomus commersonii Valenciennes, 1836 & Cascudo (3) & - & - & + & - \\
\hline Hypostomus macrops (Eigenmann \& Eigenmann, 1888) & Cascudo (2) & + & - & - & - \\
\hline Pimelodus maculatus La Cépede, 1803 & Mandi-amarelo (2) & + & - & - & - \\
\hline Rhinelepis aspera Spix \& Agassiz, 1829 & Cascudo (2) & + & - & - & - \\
\hline
\end{tabular}

Eigenmann, 1889) (20.1\%), Tetragonopterus chalceus Spix \& Agassiz, 1829 (18.1\%) and Acestrorhynchus lacustris (Lutken, 1875) (16.5\%). Captures in biomass were also highest for $S$. brandtii (24,2\% of the whole sampled weight), followed by $A$. lacustris (18.9\%), Schizodon knerii (Steindachner, 1874) (15.7\%) and C. lepidura (10.7\%) (Fig. 3).

At upstream stations, 23 species were captured. Of these, 13 were considered constant, three accessories and seven acci- 
Table II. Calculated Student $t$ test ( $t$ ) and ANOVA F test ( $F$ ) values, based on bimonthly captures in number (CPUEn) and biomass (CPUEb), among seasons (dry and wet) and samplings sites in Juramento reservoir, from March 2002 to February 2003. Significant values ( $p<$ 0.05 ) are in bold. (sd) Standard deviation, (M) mean, $(\mathrm{N})$ number of samples, (A, B) post hoc comparisons among sites by performing a Tukey test. Sites with same letters have no significant abundances.

\begin{tabular}{|c|c|c|c|c|c|c|c|}
\hline & \multicolumn{3}{|c|}{ Periods } & \multicolumn{4}{|c|}{ Sites } \\
\hline & Dry & Wet & $\mathrm{t}$ & Barragem & Canoas & Juramento & $\mathrm{F}$ \\
\hline \multicolumn{8}{|c|}{ CPUEn } \\
\hline $\mathrm{N}$ & 4 & 2 & 1.0 & 6 & 6 & 6 & 5.9 \\
\hline$M$ & 855.7 & 742.0 & & 373.1 & 601.7 & 368.3 & \\
\hline \multirow[t]{2}{*}{$s d$} & 156.7 & 0.568 & & 113.0 & 137.4 & 149.1 & \\
\hline & & & & A & B & A & \\
\hline \multicolumn{8}{|c|}{ CPUEb (g) } \\
\hline $\mathrm{N}$ & 4 & 2 & 0.3 & 6 & 6 & 6 & 2.8 \\
\hline$M$ & 5858.8 & 5646.5 & & 33529.6 & 41760.4 & 29972.9 & \\
\hline sd & 1023.3 & 488.6 & & 8562.2 & 5595.4 & 11425.7 & \\
\hline
\end{tabular}

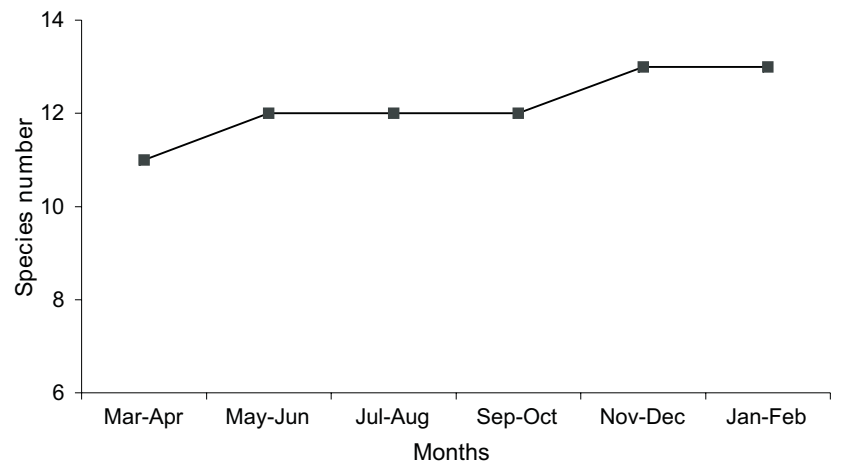

Figure 2. Fish species accumulation curve for Juramento reservoir from March 2002 to February 2003.

dental. At the Jusante station, 28 species occurred, 11 of them being accidental, 10 constant and seven accessories (Tab. III). Considering only the quantitative sampling, 12 species were identified at Barragem, 13 at Canoas and 11 at Juramento. Barragem showed the highest diversity values, according to Shannon and Simpson indexes, although with small differences in relation to other stations. Nevertheless, the Shannon index $t$ test was significant $(p<0.05)$ between Barragem and the other reservoir regions. The evenness values were also similar between stations (Tab. IV). Barragem and Juramento showed the most similarity, followed by Barragem and Canoas. Smaller values were obtained among Canoas/Juramento and Jusante stations (Tab. V).

Only the first two axis presented eigenvalues greater than one $(\mathrm{PCI}=1.91$; $\mathrm{PCII}=1.61)$, explaining together $70.5 \%$ of the total variance. PCI was related to water transparency, dissolved oxygen and $\mathrm{pH}$, while PCII described the conductivity influence. A plot of these two components described an environmental gradient explained by PCI that put samples with higher
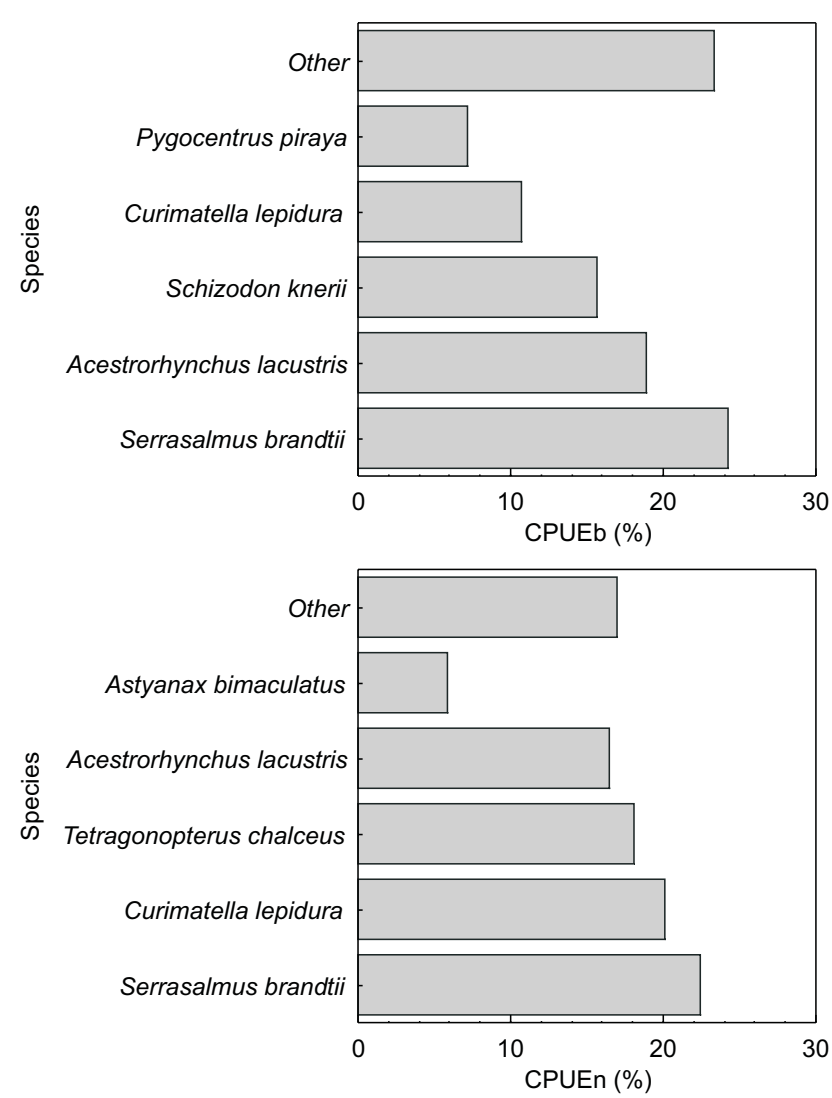

Figure 3. Percent of the total catch per unit of effort in biomass (CPUEb) and in number (CPUEn) from the captured species in Juramento reservoir, from March 2002 to February 2003.

values of DO, pH and transparency at one side, and those showing low values for these variables in the opposite; and another 
Table III. Constancy for the species upstream and downstream of the Juramento dam study area, collected from March 2002 to February 2003. (Cn) Constant, (Ac) Accessory, (Ai) Accidental.

\begin{tabular}{|c|c|c|}
\hline \multirow{2}{*}{ Species } & \multicolumn{2}{|l|}{ Constancy } \\
\hline & Upstream & Downstream \\
\hline Acestrorhynchus lacustris & $\mathrm{Cn}$ & Ac \\
\hline Astyanax bimaculatus & $\mathrm{Cn}$ & $\mathrm{Cn}$ \\
\hline Compsura heterura & $\mathrm{Cn}$ & - \\
\hline Curimatella lepidura & $\mathrm{Cn}$ & - \\
\hline Hoplias lacerdae & $\mathrm{Cn}$ & $\mathrm{Ai}$ \\
\hline Hoplias malabaricus & $\mathrm{Cn}$ & $\mathrm{Ai}$ \\
\hline Leporinus taeniatus & $\mathrm{Cn}$ & - \\
\hline Prochilodus costatus & $\mathrm{Cn}$ & $\mathrm{Cn}$ \\
\hline Pygocentrus piraya & $\mathrm{Cn}$ & Ac \\
\hline Schizodon knerii & $\mathrm{Cn}$ & $\mathrm{Cn}$ \\
\hline Serrasalmus brandtii & $\mathrm{Cn}$ & $\mathrm{Cn}$ \\
\hline Steindachnerina elegans & $\mathrm{Cn}$ & - \\
\hline Tetragonopterus chalceus & $\mathrm{Cn}$ & $\mathrm{Ai}$ \\
\hline Apareiodon piracicabae & Ac & Ac \\
\hline Bryconamericus stramineus & Ac & Ac \\
\hline Piabina argentea & Ac & Ac \\
\hline Astyanax fasciatus & $\mathrm{Ai}$ & $\mathrm{Cn}$ \\
\hline Eigenmannia virescens & $\mathrm{Ai}$ & $\mathrm{Ai}$ \\
\hline Hypostomus commersonii & $\mathrm{Ai}$ & - \\
\hline Moenkhausia costae & $\mathrm{Ai}$ & $\mathrm{Ai}$ \\
\hline Phenacogaster franciscoensis & $\mathrm{Ai}$ & $\mathrm{Cn}$ \\
\hline Poecilia vivipara & $\mathrm{Ai}$ & Ac \\
\hline Roeboides xenodon & $\mathrm{Ai}$ & $\mathrm{Ai}$ \\
\hline Brycon orthotaenia & - & $\mathrm{Ai}$ \\
\hline Hoplosternum littorale & - & Ac \\
\hline Hypostomus macrops & - & $\mathrm{Ai}$ \\
\hline Leporinus elongatus & - & $\mathrm{Cn}$ \\
\hline Leporinus piau & - & $\mathrm{Ai}$ \\
\hline Otocinclus xakriaba & - & $\mathrm{Cn}$ \\
\hline Pimelodus maculatus & - & $\mathrm{Cn}$ \\
\hline Prochilodus argenteus & - & Cn \\
\hline Rhinelepis aspera & - & $\mathrm{Ai}$ \\
\hline Salminus brasiliensis & - & $\mathrm{Ai}$ \\
\hline
\end{tabular}

gradient described by PCII from the lowest (BF02) toward the highest (JF03) conductivity value (Fig. 4).

Inexpressive correlations were obtained between CPI $(\mathrm{r}=0.005 ; \mathrm{p}=0.90)$ and CPII $(\mathrm{r}=0.139 ; \mathrm{p}=0.67)$ scores and the log-transformed CPUEn values for the fish samplings.

\section{DISCUSSION}

Just around 200 fish species from the SFR basin have been identified (Alves \& Pompeu 2001). The number found in the

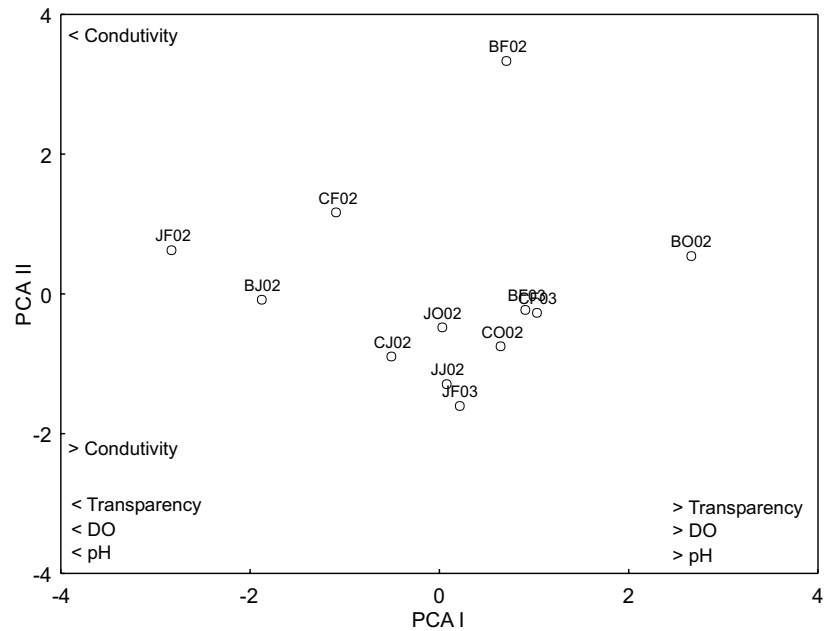

Figure 4. PCA I and PCA II axes obtained from the limnological matrix data by site/bimester for Juramento reservoir. (B) Barragem, (J) Juramento, (C) Canoas, (F) February, (J) June, (O) October, (02) 2002, (03) 2003.

Table IV. Species richness, diversities and evenness indexes estimated for upstream sampled sites of Juramento reservoir from March 2002 to February 2003 (Shannon calculated t test values in bold are significant).

\begin{tabular}{|c|c|c|c|}
\hline Indexes & Barragem & Canoas & Juramento \\
\hline Shannon $\left(\mathrm{H}^{\prime}\right)$ & 1.98 & 1.91 & 1.88 \\
\hline Simpson (1/D) & 6.21 & 5.52 & 5.53 \\
\hline Evenness $\left(\mathrm{H}^{\prime} / \log \mathrm{S}\right)$ & 0.80 & 0.70 & 0.80 \\
\hline Species richness $(\mathrm{N})$ & 12 & 13 & 11 \\
\hline \multicolumn{4}{|l|}{ t test for $\mathrm{H}^{\prime}$} \\
\hline Barragem $\times$ Canoas & & & \\
\hline Canoas $x$ Juramento & & \multicolumn{2}{|r|}{1.0} \\
\hline Barragem $x$ Juramento & & 2.8 & \\
\hline
\end{tabular}

Table V. Values of Jaccard similarity index between all sampled sites of Juramento reservoir area, from March 2002 to February 2003.

\begin{tabular}{lc}
\hline \multicolumn{1}{c}{ Sites } & Similarity \\
\hline Barragem/Canoas & 0.625 \\
Barragem/Juramento & 0.708 \\
Barragem/Jusante & 0.576 \\
Canoas/Juramento & 0.478 \\
Canoas/Jusante & 0.364 \\
Juramento/Jusante & 0.469 \\
\hline
\end{tabular}

present study (33) represents $16.5 \%$ of this total. The studied area is located near of this basin headwaters, so the captured species number correspond to what would be expected, since 
this number tends to increase progressively towards the river mouth (VANNOTE et al. 1980). A similar pattern was also found by Araújo (1996) and Petry \& Schulz (2001), among other. In a preliminary study, 15 fish species were registered for Juramento reservoir (DABÉs et al. 2001). From these, only Trachelyopterus galeatus (Linnaeus, 1766) was not captured in the present work.

Comparing with other SFR reservoir, 73 species were reported for Três Marias (Minas Gerais) (BRITski et al. 1986). Considering that this reservoir has a maximum flooded area of 1050 $\mathrm{km}^{2}$ and Juramento only $7.63 \mathrm{~km}^{2}$, the species number found for the latter is relatively high. The reduced anthropic impact suffered by this reservoir, which is located into a protected area, could explain this result.

Two species, Geophagus brasiliensis (Quoy \& Gaimard, 1824) and Callichthys callichthys (Linnaeus, 1758), considered as being abundant and having broad distribution in Velhas River basin (Alves \& POMPeu 2001), were not captured in the present work. On the other hand, in the time between the first and the last sampling, only other two species were added to cumulative curve, thus indicating a good estimate for the local species richness.

Characiformes represented $75.7 \%$ of all collected species while $18.1 \%$ were Siluriformes. From all species described for the SFR basin, each of the two above orders was accounted for 46\% (SATO \& GodinHo 1999). Higher characiforms ratios are typical of small reservoirs according to ARAújo \& SANTOS (2001). The characiform abundance could be due to fish composition changes along the years caused by Juramento River impoundment, since such actions cause deep changes in fish assemblages and directly influence species biological functions (Merona 1987). It is also important to notice the local absence of perciforms, which are common in many Brazilian reservoirs.

Only two species, Hoplosternum littorale (Hancock, 1828) and Hoplias lacerdae Ribeiro, 1908, would be introduced in Juramento based on the findings of Ribeiro (1908 apud Alves \& Pompeu 2001) and Oliveira \& Moraes Jr (1997). It is a relevant fact, considering that fish introductions, most of them with deleterious effects, have been registered for other Brazilian reservoirs (Castro \& Arcifa 1987, Alves \& Vono 1997, Alves \& Pompeu 2001). Exotic piscivorous species might radically change the fish communities structure in reservoirs as stated by SUNAGA \& VERANI (1997) and SANTOS \& Formagio (2000). In Juramento this is a real threat, since 'catch-and-pay' fish farms, one of the most important sources of fish introductions, are common in the region.

Significant higher captures in number were found only for CPUEn values at Canoas station, in the reservoir transition region. Normally, the transition region is the most fertile local, with higher ratios of primary productivity, density of fishes and light penetration (THORNTON et al. 1990). In some situations, it also shows the greatest species diversity (Benedito-Cecilio et al. 1997).

The dominance of $S$. brandtii reflects a common pattern observed in Brazilian reservoirs. Several 'piranha' and 'pirambeba' species preferentially inhabit lentic environments, a fact that could indicate the species colonization success as a consequence of habitat changes (AgostinHo \& Júlio JR 2002). The 'pirambebas' are responsible for an important amount of fish biomass found in oxbow lakes of the SFR (Braga 1964 apud Pompeu 1999). Eleven fish species were identified in the stomach content of $S$. brandtii according to POMPEU (1999). Eight of them were found in the Juramento reservoir and 5 were included between the most captured ones. This fact could explain the successful settlement observed for $S$. brandtii in Juramento reservoir.

Of the 23 species collected upstream of the dam, 13 were considered constant. This higher ratio could be due to the reservoir age (23 years), and indicates that the current ichthyofauna is formed mainly by well-succeed colonizers species.

Four of the 11 accidental species found at Jusante station are considered migratory or reophylic ones: Hypostomus macrops (Eigenmann \& Eigenmann, 1888), Rhinelepis aspera Spix \& Agassiz, 1829, Salminus brasiliensis (Cuvier, 1816) and Brycon orthotaenia Gunther, 1864. This fact suggests that the impoundment precluded these species, which, excluding B. orthotaenia, were captured in this station only during the reproductive period, between November and February. On the other hand, Prochilodus argenteus Agassiz, 1829 was constant downstream and absent upstream. This species has also been registered as the most abundant downstream of Três Marias reservoir (SATO et al. 2003).

Considering only the quantitative samplings, the species richness did not changes strongly between stations. This fact is possibly due to the small reservoir area $\left(7.63 \mathrm{~km}^{2}\right)$, that hinders an effective species richness differentiation between its regions.

No relevant differences were found for evenness and diversity between Canoas and Juramento stations, independently of the index used, which highlights the reservoir homogeneity in that areas. The higher diversity detected in the lentic region by the Shannon index reflects a slightly more proportional species abundance in that local. In fact the 4 most abundant species from each station were accounted for $70 \%$ of the total CPUEn at Barragem and $82 \%$ at Canoas and Juramento.

In this respect, the literature seems not to indicate a clear pattern concerning to differences in diversity between reservoir zones. Thus, few changes in the diversity were found between the lentic environment, the transition region and a tributary of Barra Bonita reservoir (São Paulo) (CASTRO 1997), suggesting low variability for the sampled sites. However, higher diversity values were registered for the lotic region of Segredo reservoir (Paraná) (AgostinHo et al. 1997).

Lower similarity values were found when comparing upstream with downstream stations, reflecting the fact that 10 species were found exclusively at Jusante. From these, six were migratory or reophylic species, indicating that the dam is acting as a barrier for them. Possibly, these species used to spread across the former river area, disappearing after the reservoir formation.

From the species captured upstream, only Prochilodus costatus Valenciennes, 1850 has a migratory reproductive behaviour, whereas Hypostomus commersonii Valenciennes, 1836 
is typical of lotic environments. $P$. costatus populations have dramatically decreased at Três Marias and Sobradinho reservoirs since their formation (SATO \& GodinHo 2003). The impact of river damming over the great migratory fish acts mainly on their reproductive success (AgostinHo et al. 1992). Thus, it could be supposed that reproduction and recruitment of $P$. costatus are taking place in the remaining $46 \mathrm{~km}$ upstream of the reservoir. This hypothesis is reinforced since the reservoir was formed 23 years ago, and that there is no official record about reintroduction of any species in that region. Few reophylic species were also described at Lajes reservoir (Rio de Janeiro) (ARAújo \& Santos 2001).

It has been mentioned that riverine species are typically abundant in the upper basin regions and in recently created reservoirs (Inz et al. 2002). Despite not being a recent reservoir, Juramento is located at the upper portion of the Verde Grande River basin, a fact that could explain the low number of reophylic species captured in it.

In the present study, log-transformed values of CPUEn were not significantly correlated with the PCI and PCII obtained from limnological variables, even so these components are related to these variables independent of the amount of fishes captured in each station and bimestre.

Significant correlations between ichthyofauna abundance and variables such as $\mathrm{pH}$, dissolved oxygen and temperature were not found at oxbow lakes of Araguaia river (TEJERINA-GARRO et al. 1998), as observed in the present study. However, higher fish captures were correlated with higher conductivities and temperatures and lower values of dissolved oxygen at Segredo reservoir (BINI et al. 1997).

Old reservoirs, like Juramento, have already been passed through the early unbalanced situation, thus being reasonable to suppose that their fish fauna are less affected by changes in the environmental variables as that ones measured in this work. In that case, changes in abundance would be probably more related to other determining factors such as competition, predation and food availability.

\section{ACKNOWLEDGEMENTS}

To Companhia de Saneamento de Minas Gerais (COPASA), R.E. Reis (PUC-RS) for fish identification, A. Hirsch (Fundação Biodiversitas), the COPASA (M. Ladeia, T.H. Viana, and Valdeir), and Unimontes (M.B. de Souza and G.R. Medeiros) staff.

\section{REFERENCES}

Agostinho, C.S. \& H.F. Julio JR. 2002. Observation of an invasion of the piranha Serrasalmus marginatus Valenciennes, 1847 (Osteichthyes, Serrasalmidae) into the Upper Paraná River, Brazil. Acta Scientiarum, Maringá, 24 (2): 391-395.

Agostinho, A.A.; H.F. Julio JR \& J.R. Borghetti. 1992. Considerações sobre os impactos dos represamentos na ictiofauna e medidas para sua atenuação, um estudo de caso: reservatório de Itaipu. Rev. Unimar, Maringá, 14: 89-107.
Agostinho, A.A.; L.M. Bini \& L.C. Gomes. 1997. Ecologia de comunidades de peixes da área de influência do reservatório de Segredo, p. 97-111. In: A.A. Agostinho \& L.C. Gomes (Eds). Reservatório de Segredo: bases ecológicas para o manejo. Maringá, EDUEM, 387p.

Alves, C.B.M. \& P.S. Pompeu. 2001. A fauna de peixes da bacia do rio das Velhas no final do século XX, p. 165-187. In: C.B.M. Alves \& P.S. Pompeu. (Eds). Peixes do Rio das Velhas: passado e presente. Belo Horizonte, SEGRAC, 194p.

Alves, C.B.M \& V. Vono. 1997. O caminho da sobrevivência para os peixes no rio Paraopeba. Ciência Hoje, Rio de Janeiro, 21 (126): 14-16.

Araújo, F.G. 1996. Composição e estrutura da comunidade de peixes do médio e baixo rio Paraíba do Sul, RJ. Revista Brasileira de Biologia, Rio de Janeiro, 56 (1): 111-126.

Araújo, F.G. \& L.N. Santos. 2001. Distribution of fish assemblages in Lajes reservoir, Rio de Janeiro, Brazil. Brazilian Journal of Biology, Rio de Janeiro, 61 (4): 563-576.

Benedito Cecílio, E.; A.A. Agostinho; H.F. Julio Jr \& C.S Pavanelli. 1997. Colonização ictiofaunística do reservatório de Itaipu e áreas adjacentes. Revista Brasileira de Zoologia, Curitiba, 14 (1): 1-14.

Bini, L.M; L.C. Gomes \& A.A. Agostinho. 1997. Variações na abundância de peixes na pesca experimental do reservatório de Segredo, p. 213-241. In: A.A. Agostinho \& L.C. Gomes (Eds). Reservatório de Segredo: bases ecológicas para o manejo. Maringá, EDUEM, XII+387p.

Boschung, H. \& P. Oneil. 1981. The effects of forest clear cutting on fishes and macroinvertebrates in a Alabama stream, p. 200-217. In: L.A. KRumhulz (Ed.). The Warm Water Streams Symposium. Bethesda, American Fisheries Society, 422p.

Britski, H.A.; Y. Sato \& A.B.S. Rosa.1986. Manual de identificação de peixes da região de Três Marias: com chaves de identificação para os peixes da bacia do São Francisco. Brasília, Câmara dos Deputados, Coordenação de Publicações, $115 \mathrm{p}$.

Castro, A.C.L. 1997. Aspectos ecológicos da comunidade ictiofaunística do reservatório de Barra Bonita, SP. Revista Brasileira de Biologia, Rio de Janeiro, 57 (4): 665-676.

Castro, R.M.C. \& M.S. Arcifa. 1987. Comunidade de peixes de reservatórios no Sul do Brasil. Revista Brasileira de Biologia, Rio de Janeiro, 47 (4) 493-500.

Copasa. 2001. Rios de Minas. Belo Horizonte, Editorial Sociedade Comercial, 108p.

Dabés, M.B.G.S.; G.B. Santos; T.F. Ratton, \& G.R. Medeiros. 2001. Estudo da ictiofauna na barragem do rio Juramento, Juramento/MG - Brasil. Unimontes Científica, Montes Claros, 1 (1) $105-116$.

DAJOz, R. 1973. Ecologia Geral. Petrópolis, Editora Vozes, $2^{\text {a }}$ ed., 471p.

GodinHo, A.L.; M.F.G. BRITo \& H.P. GodinHo. 2003. Pesca nas corredeiras de Buritizeiro: da ilegalidade a gestão participativa, p. 347-360. In: H.P. GodinHo \& A.L. GodinHo. (Eds). Águas, pei- 
xes e pescadores do São Francisco das Minas Gerais. Belo Horizonte, PUC-Minas, 458p.

Irz, P.; A. Laurent; S. Messad; O. Pronier \& C. Argillier. 2002. Influence of site characteristics on fish community patterns in French reservoirs. Ecology of Freshwater Fish, Madrid, 11: 123-136.

JACKSON, D.A. 1993. Multivariate analysis of benthic ivertebrate communities: the implication of choosing particular data standardizations, measures of association, and ordination methods. Hydrobiologia, Dordrecht, 268: 9-26.

MagurRan, A.E. 2004. Measuring biological diversity. Oxford, Blackwell Publishing, 258p.

Merona, B. 1987. Aspectos ecológicos da ictiofauna no baixo Tocantins. Acta Amazônica, Manaus, 16/17: 109-124.

Oliveira, J.C. \& J.R. Moraes Jr. 1997. Presença de Hoplosternum (Gill, 1858) (Teleostei, Siluriformes, Callichthyidae) nas bacias dos rios São Francisco, Paraíba do Sul e Alto Paraná: $1^{\circ}$ registro e comentários. Boletim do Museu Nacional, Nova Série Zoologia, Rio de Janeiro, 383: 1-8.

Oliveira, A.K.; M.C.C. Alvim; A.C. Peret \& C.B.M. Alves. 2004. Diet shifts related to body size of the pirambeba, Serrasalmus brandtii Lutken, 1875 (Osteichthyes, Serrasalminae) in the Cajuru reservoir, Sao Francisco river basin, Brazil. Brazilian Journal of Biology, Rio de Janeiro, 64 (1): 117-124.

Planvasf. 1989. Plano diretor para o desenvolvimento do vale do São Francisco - Relatório final. Brasília, PLANVASF, 515p.

Petry, A.C. \& U.H. Shulz. 2001. Levantamento da comunidade de peixes do rio dos Sinos, RS. Acta Biologica Leopoldensia, São Leopoldo, 23 (1): 49-58.

Pompeu, P.S. 1999. Dieta da pirambeba Serrasalmus brandtii Reinhardt (Teleostei, Characidae) em quatro lagoas marginais do rio São Francisco, Brasil. Revista Brasileira de Zoologia, Curitiba, 16 (2): 19-26.

Pompeu, P.S. \& H.P. Godinho. 2003. Dieta e estrutura trófica das comunidades de peixes de três lagoas marginais do médio São Francisco, p. 183-194. In: H.P. Godinho \& A.L. GodinHo (Eds). Águas, peixes e pescadores do São Francisco das
Minas Gerais. Belo Horizonte, PUC-Minas, 458p.

Santos, G.B. \& P.S. Formagio. 2000. Estrutura da ictiofauna dos reservatórios do rio Grande, com ênfase no estabelecimento de peixes piscívoros exóticos. Informe Agropecuário, Belo Horizonte, 21 (203): 98-106.

Sato, Y. \& H.P. Godinho. 1999. Peixes da bacia do rio São Francisco, p. 401-413. In: R.H. Lowe McConnell (Ed.). Estudos Ecológicos de Comunidades de Peixes Tropicais. São Paulo, EDUSP, 534p.

SATo, Y. \& H.P. Godinho. 2003. Migratory fishes of the São Francisco river, p. 195-232. In: J. Carolsfeld; B. Harvey; C. Ross \& A. BAER (Eds). Migratory fishes of South America. Victoria, IDRC/World Bank, 372p.

Sato, Y.; N. Bazzoli; E. Rizzo; M.A. Boschi \& M.O.T. Miranda. 2003. Impacto a jusante do reservatório de Três Marias sobre a reprodução do peixe reofilico curimatá-pacu (Prochilodus argenteus), p. 327-345. In: H.P. GodinHo \& A.L. GodinHo (Eds). Águas, peixes e pescadores do São Francisco das Minas Gerais. Belo Horizonte, PUC-Minas, 458p.

Sunaga, T. \& J.R. Verani. 1997. The Fish Communities of Four Lakes, p. 359-369. In: J.G. TundisI \& Y. SAIJO (Eds). Limnological Studies on the Rio Doce Valley Lakes, Brazil. Rio de Janeiro, Brazilian Academy of Sciences, 528p.

Tejerina-Garro, F.L.; R. Fortin \& M.A. Rodriguez. 1998. Fish community structure in relation to environmental variation in floodplain lakes of the Araguaia river, Amazon basin. Environmental Biology of Fish, Dordrecht, 51: 399-410.

Ter BraAk, C.J.F. 1995 Ordination, 91-173. In: R.H.G Jongman; C.J.F ter BRAak \& O.F.R. van TONgeren (Eds). Data analysis in community and landscape ecology. Cambridge, Cambridge University Press, 300p.

Thornton, K.W.; B.L. Kimmel \& F.E. Payne. 1990. Reservoir limnology: ecological perspectives. New York, Wiley-Interscience Publication, 246p.

Vannote, R.L.; G.W. Minshal; K. W. Cummins; J.R. Sedell \& C.E. Cushing. 1980. The river continuum concept. Canadian Journal of Fisheries and Aquatic Sciences, Ottawa, 37:130-137.

Received in 17.I.2006; accepted in 29.VIII.2006. 